\title{
IDENTIFICATION AND PRODUCTION OF PHENOLIC NICOTIFLORIN IN ASTRAGALUS CHRYSOCHLORUS CALLUS
}

\author{
NESLIHHAN TURGUT-KARA ${ }^{1}{ }^{*}$, ÖZGÜR ÇAKIR $^{1}$, SEMRA HASANÇEBI ${ }^{2}$, FATIIH KARABEY ${ }^{3}$, \\ ŞULE ARI ${ }^{1}$
}

${ }^{1}$ Istanbul University, Faculty of Science, Department of Molecular Biology and Genetics, Istanbul, Turkey

${ }^{2}$ Trakya University, Faculty of Engineering, Departmant of Genetics and Bioengineering, Edirne, Turkey

${ }^{3}$ Ege University, Faculty of Engineering, Department of Bioengineering, 35100 Bornova-Izmir, Turkey

*corresponding author: neslihantk@istanbul.edu.tr

Manuscript received: September 2016

\begin{abstract}
Astragalus chrysochlorus Boiss. \& Kotschy $(2 \mathrm{n}=16)$ is one of the rare Turkish endemic species and it is listed in the Red Data Book of Turkish Plants as endangered. This species has been used traditionally for its wound healing properties and a crude ethanol extract prepared from the roots exhibits antioxidant and cytotoxic activities. In this study, a detailed phytochemical analysis was performed on A. chrysochlorus calli that resulted in the isolation of a major constituent. The purified molecule's structure elucidation was completed by spectral methods [nuclear magnetic resonance (NMR) and mass spectrometry (MS)], which revealed a rarely encountered the flavonoid in the Astragalus genus, nicotiflorin. In order to increasing nicotiflorin content in the callus cultures, the effects of culturing time and elicitor treatment were investigated. The HPLC analyses showed that the maximal production of nicotiflorin occurred with long-term cultured (13 years old) callus as $4775 \mu \mathrm{g} / \mathrm{g}$ dry weight (DW), whereas it was $132 \mu \mathrm{g} / \mathrm{g}$ DW for short-term cultured ( 2 months old) ones. Then, the $24 \mathrm{~h}$ treatment of the yeast extract that was used as biotic elicitor had negative effect on the production of nicotiflorin. The data obtained from this study could be significant for the mass production of nicotiflorin from long term in vitro cultured $A$. chrysochlorus callus.
\end{abstract}

\section{Rezumat}

Astragalus chrysochlorus Boiss. \& Kotschy $(2 \mathrm{n}=16)$ este una dintre speciile endemice din Turcia și este încadrată în lista roșie ca fiind pe cale de dispariție. Această specie a fost folosită în mod tradițional pentru proprietățile sale de vindecare a rănilor, iar un extract etanolic a fost preparat din rădăcini şi prezintă activitate antioxidantă şi citotoxică. În acest studiu s-a efectuat o analiză fitochimică detaliată pe A. chrysochlorus calli care a dus la izolarea unui constituent major. Elucidarea moleculei purificate a fost completată prin metode spectrale (rezonanță magnetică nucleară (NMR) și spectrometrie de masă (MS)), care au evidențiat flavonoidul nicotiflorin. Pentru a crește conținutul de nicotiflorin în culturile de calus, s-au investigat efectele timpului de cultivare și tratamentul elicitor. Analizele HPLC au arătat că producția maximă de nicotiflorin a apărut la calusul de lungă durată (13 ani), $4775 \mu \mathrm{g} / \mathrm{g}$ DW, în timp ce acesta a fost de $132 \mu \mathrm{g} / \mathrm{g}$ DW pentru culturile de scurtă durată (cu vârsta de 2 luni).

Keywords: Astragalus, nicotiflorin, kaempferol 3-O-rutinoside, flavonoid, NMR, HPLC

\section{Introduction}

Phytochemicals are the richest resources for human consumption because of their various applications. By using phytochemicals, new and novel products for the treatment and prevention of serious diseases could be improved [1].

Plant secondary metabolites have significant functions in plant growth, development and physiology. The effective components of medicinal plants are usually the secondary metabolites and the synthesis of them is affected by a variety of factors, such as biotic and abiotic effectors. Also, secondary metabolites help plants to survive, defence and compete with others [2]. Thus, the production of the majority of plant phenolic compounds could be induced by the applications of abiotic and biotic elicitors. Therefore, elicitor application is usually preferred to trigger the production of rare phytochemical sources [3].

Nicotiflorin exists in a few plants, thus there are limited number of studies conducted [3]. Nevertheless, nicotiflorin isolation has been reported from Heteropappus altaicus and H. Biennis [4], Solidago canadensis [5], Ficaria verna [6], Clitoria ternatea [7], Staphylea bumalda [8], Trigonotis peduncularis [9], Acalypha indica [10], Carthamus tinctorius [11], Camellia sinensis [3], Caragana bungei [12], Solanum campaniforme [13], Osyris wightiana [14], Ampelopsis heterophylla [15], amaranth [16] and Aspergillus awamori [17]. Although it is not common among Astragalus species, nicotiflorin isolation has been reported only from Astragalus verrucosus [18] and Astragalus cruciatus [19]. 
Flavonoids are a group of polyphenolic secondary metabolites found in plants and have a variety of biological activities [20]. The bioassay results demonstrated that flavonoid nicotiflorin has a neuroprotective effects $[21,22]$, inhibitory effect on adipogenesis [23], protective effects on reducing memory dysfunction [11] and a potent inhibitor of alphaglucosidase [24]. Also, it has been shown that exerted hACAT1 (human Acyl CoA: cholesterol transferase 1) inhibitory [9], in vitro anti-glycation [14] and antioxidant activities [25].

Astragalus is used in traditional Chinese medicine because it possesses many biological activities. It has also been proven effective for clinical treatment of many diseases [26]. The well-known components of Astragalus membranaceus, are flavonoids, triterpene saponins, and polysaccharides. The phenyl-propanoid derivated flavonoids are associated with antioxidant and cytotoxic activities of these plants [27]. A vast number of studies were made about Astragalus species and its components; however, there is still so much to learn about that. A Turkish endemic, Astragalus chrysochlorus Boiss. and Kotschy has cytotoxic effects and selenium accumulation capacity [28-30].

To investigate other potential biological activities of nicotiflorin, there is need to find alternative source of nicotiflorin. Therefore, in the present study, the purified molecule's structure elucidation was completed by spectral methods (NMR and MS). HPLC analysis of different time regime and elicitor application on in vitro cultures of $A$. chrysochlorus was carried out to estimate the amount of the bioactive compound nicotiflorin.

\section{Materials and Methods}

Plant material and Callus Induction. Long-term (13 years old) and short-term (2 months old) in vitro cultured Astragalus chrysochlorus callus tissues were used as previous described in literature [31]. Divided hypocotyl explants $(\sim 0.5 \mathrm{~cm})$ from 15 -day old in vitro-germinated seedlings were used for callus induction in the presence of $0.5 \mathrm{mg} / \mathrm{L}$ of 2,4-dichlorophenoxyacetic acid (2,4-D). Fifteen explants were oriented in a horizontal position on the surface of Petri dish media and incubated in a growth chamber (Hereaus, Vötsch, No: 440/0026/86) with fluorescent light $\left(1400 \mathrm{Em}^{-2} \mathrm{~s}^{-1}\right)$ and $16 \mathrm{~h} /$ day photoperiods at $25 \pm 2{ }^{\circ} \mathrm{C}$. Five replicates were used per treatment and subcultures were done at 3 week intervals and then harvested. Harvested callus material was frozen at $-80^{\circ} \mathrm{C}$ and then lyophilized.

Extraction of Plant Material for NMR and MS Measurements. The lyophilized and powdered plant material of $A$. chrysochlorus (callus tissues; $29 \mathrm{~g}$ ) was extracted with $\mathrm{MeOH}(2 \times 5 \mathrm{~L})$ at room temperature for 12 hours. After filtration, the solvent was removed by rotary evaporation to afford $8.431 \mathrm{~g}$ of crude extract. The $\mathrm{MeOH}$ extract was subjected to vacuum liquid chromatography (VLC) on reversedphase material (Lichroprep RP-18, 25 - $40 \mu \mathrm{m}, 20 \mathrm{~g}$ ) employing $\mathrm{H}_{2} \mathrm{O}(100 \mathrm{~mL}), \mathrm{H}_{2} \mathrm{O}-\mathrm{MeOH}(85: 25$, $500 \mathrm{~mL} ; 25: 75,300 \mathrm{~mL})$, and $\mathrm{MeOH}(800 \mathrm{~mL})$ to give ten main fractions (A1-A10). TLC analyses were performed to control these fractions. After TLC, selected fractions were applied to open column chromatography using silica gel (100 g) as stationary phase. Elution was carried out with $\mathrm{CHCl}_{3}-\mathrm{MeOH}$ mixtures $(95: 5,1000 \mathrm{~mL} ; 90: 10,400 \mathrm{~mL} ; 85: 15$, $1000 \mathrm{~mL} ; 80: 20,500 \mathrm{~mL} ; 70: 30,1000 \mathrm{~mL}$ ) to other fractions (B).

Initiation of Cell Suspension Cultures and Elicitor Treatment. A. chrysochlorus primary cell suspension cultures were propagated in the dark as previously described by Cakir O. et al. [32]. The actively grown 21-day-old friable calli were used to establish cell suspension cultures. The callus ( $\sim 1.0 \mathrm{~g})$ was cut into small pieces and cultured in $50 \mathrm{~mL}$ MS medium $(3 \%$ sucrose and $1 \mathrm{mg} / \mathrm{L} \mathrm{2,4-D} \mathrm{in} 100 \mathrm{~mL}$ Erlenmeyer flask) in $250 \mathrm{~mL}$ Erlenmeyer flask for the establishment of primary cell suspension cultures. The cultures were placed on an orbital shaker (Gerhardtthermoshake), at $120 \mathrm{rpm}$ and incubated at $25 \pm 1^{\circ} \mathrm{C}$. Primary cell suspension cultures were subcultured at 10 day intervals.

For the induction experiments, $5 \mathrm{~mL}$ culture (with $1 \mathrm{~mL}$ packet cell volume) of the primary cell suspension culture was subcultured in $25 \mathrm{~mL}$ fresh MS medium [33]. Elicitor yeast extract was prepared by ethanol precipitation as described by Chen and Chen [34]. $10 \mathrm{~g} / \mathrm{L}$ concentration of yeast extract was added on the $13^{\text {th }}$ day (first day of log phase) of cell culture. Water added control samples were taken and analysed as well. Collecting of the biomass by filtering was performed $24^{\text {th }}$ hour of elicitor treatment. All experiments were done in triplicate. Filtered suspension cell cultures were frozen at $-80^{\circ} \mathrm{C}$ and then lyophilized.

Experimental Design. To test the effect of length of culturing time and elicitor treatment on nicotiflorin accumulation in $A$. chrysochlorus callus, two types of experiments were performed. In the first type of experiment, long-term cultured and well adapted callus cultures and short-term cultured callus were collected. No elicitor was added to the callus cultures. Collecting of the biomass was performed 3 weeks interval. Triplicate Petri dishes were used in all experiments. After the preparation of HPLC analysis, the nicotiflorin content were quantified. In the second type of experiment, cell suspension cultures which were originated from long-term and short-term cultured callus, exposed to yeast extract as an elicitor. After both experiment, accumulated biomass was lyophilized.

HPLC Sample Preparation. $100 \mathrm{mg}$ of Astragalus chrysochlorus powder extract obtained from samples 
which are mentioned in Table I, were sonicated four times with $5 \mathrm{~mL}$ methanol. The clear extracts were diluted with methanol to $30 \mathrm{~mL}$. Prior to HPLC analysis, the samples were filtered with a $0.45 \mu \mathrm{m}$ PTFE (polytetrafluoro-ethylene) filter to remove non-dissolved particles.

HPLC Conditions. HPLC-DAD (diode array detection) analyses were performed with an Agilent 110 series equipped with a quaternary pump, an autosampler. As analytical column a ThermoODS Hypersil C-18 column ( $250 \mathrm{~mm} \times 4.06 \mathrm{~mm}$, particle size $5 \mu \mathrm{m}$ ) was used. An acetonitrile/water and acetic acid mixture $(75: 25 \mathrm{v} / \mathrm{v})$ served as isocratic mobile phase. The total run time was 30 minutes, at a flow rate of $0.8 \mathrm{~mL} / \mathrm{min}$. A sample of $10 \mu \mathrm{L}$ was injected (partial loop injection) each run. The retention time was 6.5 min for nicotiflorin.

Calibration Curves. The standard stock solutions were prepared with methanol (1000 $\mu \mathrm{g} / \mathrm{mL}$ nicotiflorin). Six additional lower concentrated standard solutions $(1000,500,250,100,50$ and $10 \mu \mathrm{g} / \mathrm{mL})$ were prepared by diluting the standard stock solutions with methanol. The solutions were stored at $4^{\circ} \mathrm{C}$. Concentrations and peak areas were log transformed and the calibration curve was prepared using these values. Regression coefficients were 0.99972 for nicotiflorin (kaempferol 3-O-rutinoside). Specificity was determined by calculation of peak purity facilitated by the photodiode array detector (PDA).

\section{Results and Discussion}

Metabolic content analysis. The lyophilized callus material of Astragalus chrysochlorus was extracted with $\mathrm{MeOH}$. After filtration and solvent remove, crude extract was obtained. The $\mathrm{MeOH}$ extract was subjected to vacuum liquid chromatography (VLC) on reversed-phase material employing $\mathrm{H}_{2} \mathrm{O}, \mathrm{H}_{2} \mathrm{O}$ $\mathrm{MeOH}$ and $\mathrm{MeOH}$ to give ten main fractions (A1A10). After TLC assays, eight fractions (A3-A10) were found to be rich in flavonoids. These fractions (1.34 g) were applied to open column chromatography using silica gel as stationary phase. Elution was carried out with $\mathrm{CHCl}_{3}-\mathrm{MeOH}$ mixtures to give fifty-nine fractions (B). Compound 1 was obtained from fraction B11-B20 (98.4 mg). Specifications of compound 1: 1H-NMR (methanol-d4, $400 \mathrm{MHz}), \delta 8.03(2 \mathrm{H}, \mathrm{d}$, $\left.\mathrm{J}=8.3 \mathrm{~Hz}, \mathrm{H}-3^{\prime}, \mathrm{H}-5^{\prime}\right), 6.97(2 \mathrm{H}, \mathrm{d}, \mathrm{J}=8.3 \mathrm{~Hz}$, $\left.\mathrm{H}-2^{\prime}, 6^{\prime}\right), 6.35(1 \mathrm{H}, \mathrm{d}, \mathrm{J}=2.1 \mathrm{~Hz}, \mathrm{H}-8), 6.16(1 \mathrm{H}, \mathrm{d}$, $\mathrm{J}=1.8 \mathrm{~Hz}, \mathrm{H}-6), 5.09(1 \mathrm{H}, \mathrm{d}, \mathrm{J}=7.2 \mathrm{~Hz}$, glc H-1), $4.51(1 \mathrm{H}, \mathrm{d}, \mathrm{J}=1.4 \mathrm{~Hz}$, rha $\mathrm{H}-1), 3.80(1 \mathrm{H}, \mathrm{dd}$, $\mathrm{J}=1.0,10.4 \mathrm{~Hz}$, glc H-6), $3.38(1 \mathrm{H}, \mathrm{dd}, \mathrm{J}=4.7$, $10.8 \mathrm{~Hz}$, glc H-6), $1.12(3 \mathrm{H}, \mathrm{d}, \mathrm{J}=6.2 \mathrm{~Hz}$, rha H-6); 13 C-NMR (methanol- d4 ,100 MHz), $\delta 177.9$ (C-4), 164.5 (C-7), 162.0 (C-5), 160.0 (C-4'), 158.0 (C-9), 157.0 (C-2), 134.1 (C-3), 131.1 (C-2', C-6'), 121.3 (C-1'), 114.7 (C-3' , C-5' ), 104.2 (C-10), 103.3 (glc C-1), 100.9 (rha C-1), 98.6 (C-6), 93.6 (C-8), 76.7 (glc C-3), 75.7 (glc C-5), 74.3 (glc C-2), 72.5 (rha C-4), 70.9 (rha C-3), 70.6 (rha C-2), 70.0 (glc C-4), 68.3 (rha C-5), 67.2 (glc C-6), 16.5 (rha C-6).

Successive purification of the flavonoid rich fraction on silica gel and RP (C-18) columns yielded a pure metabolite. Compound 1 (Figure 1) was obtained as a yellow amorphous powder. Its molecular formula was determined as $\mathrm{C}_{27} \mathrm{H}_{30} \mathrm{O}_{15}$ by LC-MS, ${ }^{1} \mathrm{H}$ - and ${ }^{13} \mathrm{C}-\mathrm{NMR}$ data. The ${ }^{1} \mathrm{H}-\mathrm{NMR}$ resonances at $\delta 8.03$ $(\mathrm{d}, \mathrm{J}=8.3 \mathrm{~Hz}, 2 \mathrm{H})$ and $\delta 6.97(\mathrm{~d}, \mathrm{~J}=8.3 \mathrm{~Hz}, 2 \mathrm{H})$, together with those at $\delta 6.35(\mathrm{~d}, \mathrm{~J}=2.1 \mathrm{~Hz}, 1 \mathrm{H})$ and $\delta 6.16(\mathrm{~d}, \mathrm{~J}=1.8 \mathrm{~Hz}, 1 \mathrm{H})$ revealed 1,4-disubstituted and 1,2,3,5-tetrasubstituted aromatic rings, respectively, implying a flavonoid skeleton. Additionally, in the ${ }^{1} \mathrm{H}-\mathrm{NMR}$ spectrum, two anomeric protons observed at $\delta 5.09(\mathrm{~d}, \mathrm{~J}=7.2 \mathrm{~Hz})$ and $\delta 4.51(\mathrm{~d}, \mathrm{~J}=1.4 \mathrm{~Hz})$ suggested a flavonoid diglycoside framework. Detailed inspection of the ${ }^{1} \mathrm{H}$ - and ${ }^{13} \mathrm{C}-\mathrm{NMR}$ signals and comparison of the obtained data with those in the literature verified compound 1 as kaempferol-3O-rutinoside (nicotiflorin) [12, 23] which is uncommon in Astragalus genus [18].

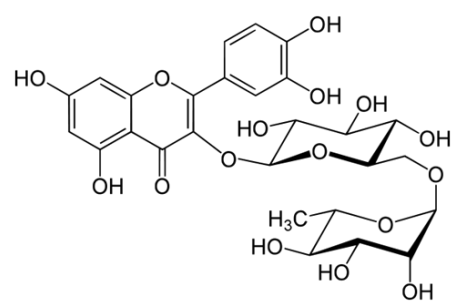

Figure 1.

Molecular structure of nicotiflorin (kaempferol 3O-rutinoside)

Effects of culture time and elicitation on nicotiflorin production

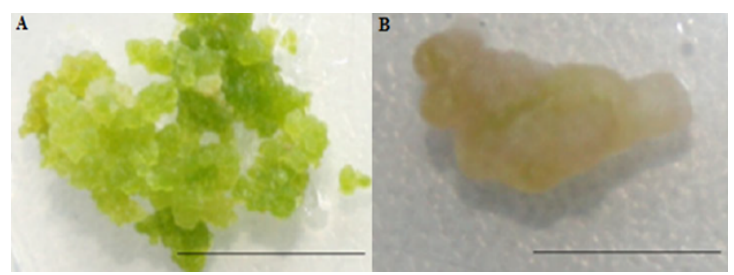

Figure 2.

Astragalus chrysochlorus callus cultures. A: Longterm cultured callus; B: Short-term cultured callus [31]. Bar: $1 \mathrm{~cm}$

Obtainment of the secondary metabolites via callus culture has the advantage of low cost and less environmental impact [35]. But there is a strong association between callus yield and culture adaptation. Within the presented work, A. chrysochlorus callus and suspension cultures were tested with or without elicitor yeast extract applied conditions to enhance nicotiflorin yield. Very few amount of nicotiflorin production was observed on the tested conditions 
FARMACIA, 2018, Vol. 66, 1

except long-term cultured callus which was cultured for 13 years (subcultured 20 days intervals) and

well adapted to tissue culture conditions (Figure 2; Table I).

Table I

Nicotiflorin production profile of the tested conditions given as dry weight (DW)

\begin{tabular}{lc}
\hline Sample Origin (10 $\mathbf{~ m g} / \mathbf{m l})$ & Nicotiflorin $\mathbf{( 3 5 0} \mathbf{~ n m})$ \\
\hline LT cultured callus, non-elicited & $4775 \mu \mathrm{g} / \mathrm{g}$ \\
\hline ST cultured callus, non-elicited & $132 \mu \mathrm{g} / \mathrm{g}$ \\
\hline LT cultured callus derived CSC control & $8.5 \mu \mathrm{g} / \mathrm{g}$ \\
\hline LT cultured callus derived CSC elicited & $10 \mu \mathrm{g} / \mathrm{g}$ \\
\hline ST cultured callus derived CSC control & $140 \mu \mathrm{g} / \mathrm{g}$ \\
\hline ST cultured callus derived CSC elicited & $10 \mu \mathrm{g} / \mathrm{g}$ \\
\hline
\end{tabular}

LT: Long-Term; ST: Short-Term; CSC: Cell Suspension Culture

When considering of the adaptation of cells, minor physical or chemical changes can cause significant differences. In some cases, cells not even continue to live. But the adapted ones, survive by gaining new advantageous features. Binh et al [36] reported that rice (Oryza sativa L.) cells, grown under a continuous stress $\mathrm{NaCl}$, produced a homogeneous mass of dry, compact, nodular callus with high regeneration potential. As regards, different salt stress regimes induced different advantageous features in the cultured cells [36]. On potato cultures, salinity reduced the growth rate and increased lipid peroxidation in salt-stressed line, which remained unaltered in the adapted line. $\mathrm{Na}$ and $\mathrm{Cl}$ content increased due to salinity in both lines, but the adapted line displayed greater $\mathrm{K} / \mathrm{Na}$ ratio then the stressed one. Electron microscopy showed that neither the structural integrity of the cells nor the membrane structure was affected by salinity, but plastids from adapted cells had higher starch content [37]. Another example for the adaptation is about the investigations on five years maintained transgenic Catharanthus roseus plants. They were showed that alkaloid vindoline accumulation of the transgenic plants were two times more compared to non-transformed ones. Their alkaloid profile was almost constant during 5 years [39].

In this study, suspension cells originated from both long-term and short-term cultured calli were negatively affected by 24 hour elicitation. However, abiotic elicitor copper sulphate treatment on cell cultures of Digitalis lanata was induced the flavonoid production over 10 times more compared to the control [38]. The results obtained from this study showed that $24 \mathrm{~h}$ treatment of yeast extract decreased the production of nicotiflorin in Astragalus chrysochlorus suspension cultures according to callus culture. It was concluded that other stressors, biotic or abiotic, could be applied to increase the production of this valuable compound in A. chrysochlorus.

\section{Conclusions}

In this study, the nicotiflorin content of Astragalus chrysochlorus is reported for the first time. Long-term cultured $A$. chrysochlorus calli are also very productive in terms of secondary metabolite nicotiflorin and could be consider as an ideal source for the biotechnological production of nicotiflorin.

\section{Acknowledgement}

This study was financially supported by the Research Fund of the Istanbul University (Project numbers 40151). We thank Prof. Dr. Erdal Bedir for comments that greatly improved the manuscript.

\section{References}

1. Newman DJ, Cragg GM, Snader KM, Natural products as sources of new drugs over the period 1981-2002. J Nat Prod., 2003; 66(7): 1022-1037.

2. Ramirez-Estrada K, Vidal-Limon H, Hidalgo D, Moyano E, Elicitation, an effective strategy for the biotechnological production of bioactive high-added value compounds in plant cell factories. Molecules, 2016; 21(2): 1-24.

3. Lee HB, Kim EK, Park SJ, Bang SG, Isolation and characterization of nicotiflorin obtained by enzymatic hydrolysis of two precursors in tea seed extract. $J$ Agricul Food Chem., 2010; 58(8): 4808-4813.

4. Bader G, Tuja D, Wray V, Hiller K, Flavonol glycosides from Heteropappus altaicus and H. biennis. Planta Med., 1993; 59(3): 284-285.

5. Apati P, Szentmihalyi K, Balazs A, Baumann D, HPLC analysis of the flavonoids in pharmaceutical preparations from Canadian goldenrod (Solidago canadensis). Chromatographia, 2002; 56: S65-S68.

6. Tomczyk M, Gudej J, Sochacki M, Flavonoids from Ficaria verna huds. Zeitschrift Fur Naturforschung C-a J Biosci., 2002; 57(5-6): 440-444.

7. Kazuma K, Noda N, Suzuki M, Malonylated flavonol glycosides from the petals of Clitoria ternatea. Phytochemistry, 2003; 62(2): 229-237.

8. Sohn SJ, Kwon YS, Kim SS, Chun WJ, Chemical constituents of the leaves of Staphylea bumalda. Nat Prod Sci, 2004; 10(4): 173-176.

9. Yang HJ, Song MC, Bang MH, Lee JH, Development of biologically active compounds from edible plant sources-XII. Flavonol glycosides from Trigonotis peduncularis benth and its hACAT1 inhibitory activity. J Korean Soc Appl Biol Chem., 2005; 48(1): 98-102.

10. Nahrstedt A, Hungeling M, Petereit F, Flavonoids from Acalypha indica. Fitoterapia, 2006; 77(6): 484-486. 
FARMACIA, 2018, Vol. 66, 1

11. Huang JL, Fu ST, Jiang YY, Cao YB, Protective effects of nicotiflorin on reducing memory dysfunction, energy metabolism failure and oxidative stress in multi-infarct dementia model rats. Pharmac Biochem Behavior, 2007; 86(4): 741-748.

12. Olennikov DN, Tankhaeva LM, Partilkhaev VV, Rokhin AV, Chemical constituents of Caragana bungei shoots. Revista Brasileira De Farmacognosia (Braz J Pharmacog.), 2012; 22(3): 490-496.

13. Torres MC, das Chagas LPF, Braz-Filho R, Silveira ER, Antiophidic solanidane steroidal alkaloids from Solanum campaniforme. J Nat Products, 2011; 74(10): 2168-2173.

14. Lal Shyaula S, Abbas G, Siddiqui H, Sattar SA, Synthesis and antiglycation activity of kaempferol3-O-rutinoside (nicotiflorin). Med Chem., 2012; 8(3): 415-420.

15. Chen P, Wu D, Pan Y, Separation and purification of antioxidants from Ampelopsis heterophylla by countercurrent chromatography. J Sep Sci., 2013; 36(23): 3660-3666.

16. Kraujalis P, Venskutonis PR, Kraujaliene V, Pukalskas A, Antioxidant properties and preliminary evaluation of phytochemical composition of different anatomical parts of amaranth. Plant Foods Hum Nutr., 2013; 68(3): 322-328.

17. Lin S, Zhu QQ, Wen LR, Yang B, Production of quercetin, kaempferol and their glycosidic derivatives from the aqueous-organic extracted residue of litchi pericarp with Aspergillus awamori. Food Chem., 2014; 145: 220-227.

18. Pistelli L, Giachi I, Lepori E, Bertoli A, Further saponins and flavonoids from Astragalus verrucosus Moris. Pharmac Biol., 2003; 41(8): 568-572.

19. Benchadi W, Haba H, Lavaud C, Harakat D, Secondary metabolites of Astragalus cruciatus Link. and their chemotaxonomic significance. Rec Nat Products, 2013; 7(2): 105-113.

20. Kumar S, Pandey AK, Chemistry and biological activities of flavonoids: an overview. Sci World J., 2013; 2013: 1-16.

21. Nakayama M, Aihara M, Chen YN, Araie M, Neuroprotective effects of flavonoids on hypoxia-, glutamate-, and oxidative stress-induced retinal ganglion cell death. Mol Vision, 2011; 17(195-97): 1784-1793.

22. Li RP, Guo ML, Zhang G, Xu XF, Neuroprotection of nicotiflorin in permanent focal cerebral ischemia and in neuronal cultures. Biol \& Pharmac Bull., 2006; 29(9): 1868-1872.

23. Jang YS, Wang ZQ, Lee JM, Lee JY, Screening of Korean natural products for anti-adipogenesis properties and isolation of kaempferol-3-O-rutinoside as a potent anti-adipogenetic compound from Solidago virgaurea. Molecules, 2016; 21(2): 1-11.

24. Habtemariam S, A-glucosidase inhibitory activity of kaempferol-3-O-rutinoside. Nat Prod Commun., 2011; 6(2): 201-203.
25. Abreu PM, Braham H, Ben Jannet H, Mighri Z, Antioxidant compounds from Ebenus pinnata. Fitoterapia, 2007; 78(1): 32-34.

26. Zhong YF, Deng YY, Chen YP, Therapeutic use of traditional Chinese herbal medications for chronic kidney diseases. Kidney Int., 2013; 84(6): 1108-1118.

27. Shahzad M, Shabbir A, Wojcikowski K, Wohlmuth H, The antioxidant effects of Radix Astragali (Astragalus membranaceus and related species) in protecting tissues from injury and disease. Curr Drug Targets, 2016; 17(12): 1331-1340.

28. Karagoz A, Turgut-Kara N, Cakir O, Demirgan R, Cytotoxic activity of crude extracts from Astragalus chrysochlorus (Leguminosae). Biotech \& Biotech Equip., 2007; 21(2): 220-222.

29. Cakir O, Turgut-Kara N, Ari S, Zhang B, De novo transcriptome assembly and comparative analysis elucidate complicated mechanism regulating Astragalus chrysochlorus response to selenium stimuli. PLoS One, 2015; 10(10): 1-16.

30. Cakir O, Candar-Cakir B, Zhang BH, Small RNA and degradome sequencing reveals important micro RNA function in Astragalus chrysochlorus response to selenium stimuli. Plant Biotech J., 2016; 14(2): 543-556.

31. Turgut-Kara N, Kahraman BU, Effects of longterm culture of Astragalus chrysochlorus callus on morphology, genetic structure, gene expression and metabolism. Plant Biosyst., 2015; 149(2): 329-336.

32. Cakir O, Ari S, Defensive and secondary metabolism in Astragalus chrysochlorus cell cultures, in response to yeast extract stressor. J Environ Biol., 2009; 30(1): 51-55.

33. Murashige T, Skoog F, A revised medium for rapid growth and bioassays with tobacco cultures. Phys Plantarum, 1962; 15: 473-497.

34. Chen H, Chen F, Effect of yeast elicitor on the secondary metabolism of Ti-transformed Salvia miltiorrhiza cell suspension cultures. Plant Cell Rep., 2000; 19(7): 710-717.

35. Fang HY, Zhu H, Ding HM, Han HR, Research progress on effect factors of secondary metabolites content in callus. Zhongguo Zhong Yao Za Zhi, 2014; 39(15): 2846-2850.

36. Binh DQ, Fabian F, Heszky LE, Responses to continuous and discontinuous $\mathrm{NaCl}$ stress of longterm cultured rice (Oryza sativa L.) cells. Acta Biol Hun., 1993; 44(2-3): 197-210.

37. Queiros F, Rodrigues JA, Almeida JM, Almeida DPF, Differential responses of the antioxidant defence system and ultrastructure in a salt-adapted potato cell line. Plant Phys Biochem., 2011; 49(12): 1410-1419.

38. Bota C, Deliu C, The Effect of copper sulphate on the production of flavonoids in Digitalis lanata cell cultures. Farmacia, 2011; 59(1): 113-118.

39. Verma P, Sharma A, Khan SA, Mathur AK, Morphogenetic and chemical stability of long-term maintained Agrobacterium-mediated transgenic Catharanthus roseus plants. Nat Prod Res., 2015; 29(4): 315-320. 